\title{
충 \\ U.S. GEOLOGICAL SURVEY GROUND-WATER STUDIES IN KANSAS
}

\section{GROUND-WATER ISSUES}

Kansas relies on ground-water sources for public, rural, industrial, and irrigation supplies. In the western two-thirds of the State, ground water is abundant and provides most of the water supplies. Ground water is limited in the eastern one-third of Kansas, and surface water provides most of the supplies. Ground-water sources supply about 5.6 billion gallons per day (bgd), or 85 percent of the water used in Kansas. Public and rural systems provide ground water to almost 1.2 million people (about 49 percent of the State's population). About 93 percent of the ground water withdrawn (5.2 bgd) is used for irrigation, 3 percent for public supply $(0.14 \mathrm{bgd}), 3.4$ percent for industrial use $(0.19 \mathrm{bgd})$, and 0.6 percent for livestock $(0.04 \mathrm{bgd})$. The major issues related to ground water in Kansas are:

- Effects of agricultural land use on water quality, and

- Potential contamination from the disposal of hazardous wastes.

\section{U.S. GEOLOGICAL SURVEY PROGRAMS}

The U.S. Geological Survey (USGS), established in 1879, is the principal source of scientific and technical expertise in the earth sciences within the Federal government. USGS activities include research and services in the fields of geology, hydrology, and cartography. The mission of the Water Resources Division of the USGS is to develop and dissimenate scientific information on the Nation's water resources. The activities of the Water Resources Division in Kansas are conducted by scientists, technicians, and support staff in offices in Lawrence and Garden City.

The USGS gathers data from about 2,100 hydrologic stations in Kansas. The stations form a water-resources-data network to record stage, discharge, chemical quality, and sediment yield of streams; stage, storage, content, and chemical quality of lakes and reservoirs; amounts and chemical quality of precipitation; and water levels and chemical quality of ground water. Hydrologic data are stored in the USGS National Water-Data Storage and Retrieval System data base. These data are used by water planners, managers, and regulatory agencies involved in decisions that affect Kansas' water resources.

During 1987, the USGS maintained a network of about 1,800 observation wells to monitor the response of ground-water systems to natural climatic variations and the effects of pumpage. In addition, water samples for chemical analysis were collected from a statewide network of 245 wells to define water quality for each of the 14 ground-water regions in the State, which generally correspond to the principal aquifers.
The first water-resources investigation by the USGS in Kansas was completed in 1886. Since then, the USGS has conducted more than 350 hydrologic investigations in Kansas that have resulted in more than 550 reports available to the scientific community, water-resources planners, and the general public. During fiscal years 1985 and 1986, the USGS entered into cooperative agreements with 16 Federal, State, and local agencies involving 43 hydrologic investigations in Kansas; 28 of these investigations included studies of ground-water quantity and quality. Three examples of ground-water investigations conducted by the USGS that address specific ground-water issues in Kansas are discussed in the following sections.

\section{Potential Contamination from Agricultural Pesticides}

The use of pesticides for effective crop production or range management is common to nearly all farms in Kansas. Application rates of the more common pesticides can be large enough to cause degradation of ground-water quality. This degradation depends on such factors as soil type, depth from land surface to ground water, solubility and half-life of the pesticide, and quantity of precipitation and irrigation. Owing to the widespread use of pesticides, information is needed on the potential for ground-water contamination by agricultural pesticides. The USGS, in cooperation with the Kansas Department of Health and Environment (KDHE), has estimated the amounts of pesticides applied in Kansas. Five sites are being used as outdoor laboratories to evaluate the rate of vertical migration of pesticides in the unsaturated zone and to determine the persistence and movement of these compounds in ground water. Analytical procedures for simulating pesticide movement are

\section{STUDY AREAS}

$$
\begin{gathered}
\text { Agricultural } \\
\text { pesticides }
\end{gathered} \begin{gathered}
\text { Hazardous } \\
\text { wastes } \\
\text { alluvium }
\end{gathered}
$$

\section{- Hazardous wastes}

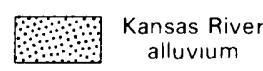

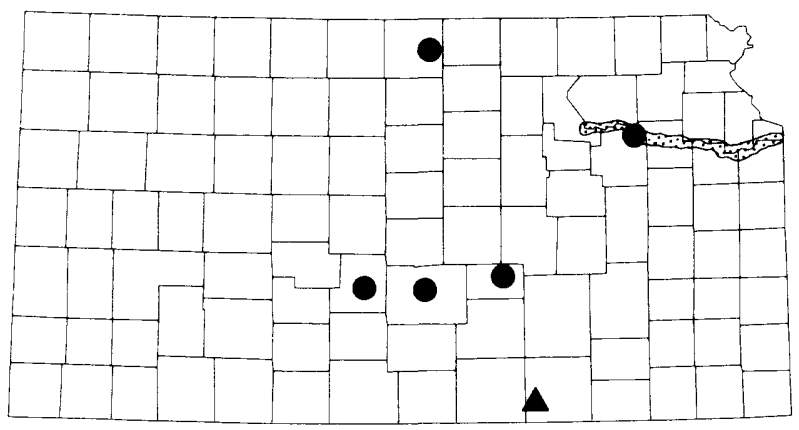


being studied. The results will be used by the KDHE to define water-quality-management priorities and to develop policies for ground-water protection

\section{Potential Contamination from Hazardous Wastes}

Kansas relies on ground water as a critical economic resource; much of that resource is contained in relatively shallow aquifers. Identification of the potential effects of the handling, disposal, and storage of hazardous materials is needed to define enforcement policies and to facilitate cleanup of contaminated areas. The USGS, in cooperation with the KDHE, is investigating contaminant characteristics and movement in the subsurface from past petroleum-refinery waste-disposal activities. An abandoned oil refinery and an active landfill near Arkansas City are being studied to define the composition and extent of hazardous wastes, to describe the past movement of petroleum products through the subsurface, and to identify persisent compounds. Another study being conducted by the USGS, in cooperation with Kansas State University, will evaluate alternative cleanup strategies for refinery sites contaminated by petroleum wastes

\section{Ground- and Surface-Water Relations in the Kansas River Alluvium}

Kansas is developing a water-management plan for the Kansas River in relation to the purchase of water stored in Federal surface-water reservoirs. The effect of pumpage from the adjacent alluvium on water releases from the reservoirs in time of drought needs to be determined. The Kansas Water Office and the Kansas State Board of Agriculture, Division of Water Resources, need accurate determinations of reservoir releases to be able to coordinate ground-and surface-water withdrawals. The USGS is developing computer models to simulate the stream-aquifer relations in the Kansas River valley. Simulation procedures established in this study, in combination with surfacewater-allocation criteria developed in a concurrent study conducted by the U.S. Bureau of Reclamation, will be used by State and Federal agencies to allocate surface and ground water to users in the Kansas River valley.

\section{GROUND-WATER MANAGEMENT}

Kansas has five State agencies and five State political subdivisions with major responsibilities for managing ground water. The Kansas Water Office is the water planning, policy, and coordinating agency for the State, and prepares State plans for water-resource management, conservation, and development. The Kansas Water Authority, a part of the Kansas Water Office, is responsible for advising the Governor, Legislature, and Director of the Kansas Water Office on water-policy issues. The Kansas State Board of Agriculture, Division of Water Resources, administers laws related to the conservation and use of water resources, including the appropriation of ground water. The Kansas Department of Health and Environment, Division of Environment, has regulatory authority in matters dealing with surface- and ground-water quality. This agency is responsible for collecting, analyzing, and interpreting ground-water-quality data, for developing water-quality-management plans, and for responding to emergency water-pollution problems. The Kansas Corporation Commission has a mandate to protect fresh ground-water supplies from adverse effects of mineraldevelopment activities. The Kansas Geological Survey conducts ground-water research, including the collection, analysis, and interpretation of data on ground-water quantity and quality.

Five Groundwater Management Districts, locally-managed political subdivisions of the State, have been formed in Kansas. Each District is charged with managing ground-water resources within its boundaries. All 10 State entities use ground-water data and the results of ground-water studies provided by the U.S. Geological Survey to carry out their responsibilities. During 1987-88, the following Federal, State, and local agencies entered into interagency or cooperative cost-sharing agreements with the USGS to conduct ground-water investigations in Kansas:

City of Wichita

Equus Beds Groundwater Management District No. 2

Kansas Department of Health and Environment

Division of Environment

Kansas Geological Survey

Kansas State Board of Agriculture

Division of Water Resources

Kansas State University

Kansas Water Office

Sedgwick County

Southwest Kansas Groundwater Management District No. 3

Western Kansas Groundwater Management District No. 1

U.S. Bureau of Reclamation

U.S. Environmental Protection Agency

U.S. Fish and Wildlife Service

U.S. Soil Conservation Service

\section{SELECTED REFERENCES}

Combs, L.J., 1984, Water-resources reports prepared by or in cooperation with the U.S. Geological Survey, Kansas, 1886-1983: U.S. Geological Survey Open-File Report 84-609, 117 p.

Combs, L.J., compiler, 1987, Water-resources activities of the U.S. Geological Survey in Kansas-Fiscal years 1985 and 1986: U.S. Geological Survey Open-File Report 87-211, 108 p.

Spruill, T.B., 1983, Statistical summaries of selected chemical constituents in Kansas ground-water supplies, 1976-81: U.S. Geological Survey Open-File Report 83-263, 29 p.

U.S. Geological Survey, 1984, National water summary 1983Hydrologic events and issues: U.S. Geological Survey Water-Supply Paper 2250, 243 p.

1985, National water summary 1984-Hydrologic events, selected water-quality trends, and ground-water resources: U.S. Geological Survey Water-Supply Paper 2275, 467 p.

Information on technical reports and data related to ground water in Kansas can be obtained from:

District Chief

U.S. Geological Survey

Water Resources Division

1950 Constant Avenue

Campus West

Lawrence, Kansas 66046

Director

Kansas Water Resources Research Institute

Kansas State University

Manhattan, Kansas 66506

Director

Kansas Geological Survey

1930 Constant Avenue

Campus West

Lawrence, Kansas 66046

Open-File Report 88-160 L.J. Combs and T.L. Huntzinger, 1988 